\title{
PCR Detection of Scopulariopsis brevicaulis
}

\author{
MILENA KORDALEWSKA and ANNA BRILLOWSKA-DĄBROWSKA* \\ Molecular Biotechnology and Microbiology Department, Faculty of Chemistry \\ Gdańsk University of Technology, Gdańsk, Poland
}

Submitted 9 July 2014, revised 5 November 2014, accepted 13 November 2014

\begin{abstract}
Scopulariopsis brevicaulis is known as the most common etiological factor of the mould toenail infections. There are also reports indicating that $S$. brevicaulis could cause organ and disseminated infections. Nowadays microscopic observations from the direct sample and culture are crucial for the appropriate recognition of the infection. In this paper a PCR-based method for S. brevicaulis detection is presented. The specificity of the reaction was confirmed, as positive results were obtained only for tested S. brevicaulis isolates and no positive results were obtained for other moulds, dermatophytes, yeast-like fungi, and human DNA.
\end{abstract}

Ke y words: Scopulariopsis brevicaulis, onychomycosis, PCR

Scopulariopsis brevicaulis is a soil saprophytic mould. This non-dermatophytic filamentous fungus colonises plantar, animal and human tissues (Filipello Marchisio et al., 2000). Traditionally, it has not been considered a common human pathogen. However, the number of cases showing its pathogenicity is still increasing. The most common type of infection caused by $S$. brevicaulis is onychomycosis. Its prevalence is estimated to be $3-10 \%$ of total number of onychomycosis cases. The clinical manifestation is generally recognised as distal and lateral subungual onychomycosis (DLSO) (Stefanato and Verdolini, 2009; Gupta et al., 2012). There are also cases of smooth skin and subcutaneous tissue infections caused by S. brevicaulis (Dhar and Carey, 1993; Bryuynzel and Starink, 1998; Anandan et al., 2008). Moreover, S. brevicaulis has been reported as the cause of such infections as endocarditis (Gentry et al., 1995; Migriono et al., 1995; Jain etal., 2011), keratitis (Del Prete etal., 1994; Lotery etal., 1994), endophthalmitis (Gariano and Kalina, 1997), sinusitis (Gluck et al., 2011), fungus ball (Endo et al., 2002; Satyavani et al., 2010), otomycosis (Hennequin et al., 1994; Besbes et al., 2002), pneumonia (Issakainen et al., 2010), cerebral phaeohyphomycosis and brain abscess (Hart et al., 2001), disseminated infection causing skin lesions including a patient with acquired immune deficiency syndrome (AIDS) (Dhar and Carey, 1993), disseminated infections after bone marrow transplant (Neglia et al., 1987; Phillips et al., 1989; Krisher et al.,
1995) and after lung transplant (Wuyts et al., 2005). Disseminated S. brevicaulis infections are hard to treat and have high mortality rates, especially in immunocompromised patients. S. brevicaulis disseminated infections might be clinically and histologically indistinguishable from disseminated aspergillosis, fusariosis or zygomycosis (Salmon et al., 2010; Swick et al., 2010; Vignon et al., 2011). The data considering S. brevicaulis susceptibility are scarce and often inconsistent. The reports indicate that $S$. brevicaulis is a multi resistant fungus (Cuenca-Estrella et al., 2003).

In this paper we present a PCR-based method developed for the detection of S. brevicaulis. By a two-step extraction procedure followed by PCR and electrophoresis, the method enables fast identification of this pathogen.

Reference strains: S. brevicaulis (CBS 112377), Scopulariopsis fusca (IHEM 14552; IHEM 25912), Scopulariopsis asperula (IHEM 2546), Scopulariopsis cinerea (IHEM 25417) and other fungal isolates were obtained from the Microbiology Department of Gdańsk University of Technology (Poland). Three animal (rabbit)derived S. brevicaulis isolates (isolated from superficial infections) were obtained from the Department of Preclinical Sciences of Warsaw University of Life Sciences (Poland). One human-derived S. brevicaulis isolate (isolated from superficial infection) was obtained from the Department and Clinic of Dermatology, Venereology and Allergology of Wroclaw Medical University

* Corresponding author: A. Brillowska-Dąbrowska, Molecular Biotechnology and Microbiology Department, Faculty of Chemistry, Gdańsk University of Technology, Gdańsk, Poland; e-mail: annbrill@pg.gda.pl 
(Poland) (Table I). All isolates were identified by observation of macro- and micromorphology. Isolates were cultured on Sabouraud medium (Biomerieux, France) and incubated for up to 14 days at room temperature. DNA from samples (pieces of mycelium of 3-5 mm diameter) was extracted by a 10-min incubation of the sample in $100 \mu \mathrm{l}$ of extraction buffer $(60 \mathrm{mM}$ sodium bicarbonate $\left[\mathrm{NaHCO}_{3}\right], 250 \mathrm{mM}$ potassium chloride $[\mathrm{KCl}]$ and $50 \mathrm{mM}$ Tris, $\mathrm{pH} 9.5)$ in $95^{\circ} \mathrm{C}$ and subsequent addition of $100 \mu \mathrm{l}$ anti-inhibition buffer (2\% bovine serum albumin). After vortex mixing, this DNAcontaining solution was used for PCR (BrillowskaDąbrowska et al., 2010). Reagents were, unless otherwise stated, purchased from Sigma (Germany).

On the basis of alignment (VectorNTI; InforMax, Inc., USA) of sequences of $\beta$-tubulin gene presented in the NCBI nucleotide database, $S$. brevicaulis - specific primers Sbfor (5'AACAAACCCACTTCCCGTCGTTT3') and Sbrev (5'ACATATTTGTTTCCCGAAGCCTTTAG3') were designed. One S. brevicau-

Table I

Organisms used in the study (161 isolates)

\begin{tabular}{|c|c|c|}
\hline \multicolumn{2}{|r|}{ Organism } & No of isolates \\
\hline \multirow[t]{35}{*}{ moulds } & $\begin{array}{l}\text { Scopulariopsis brevicaulis } \\
\text { (reference strain) }\end{array}$ & 1 \\
\hline & S. brevicaulis (clinical isolates) & $\begin{array}{c}4 \\
(1 \text { human-derived }) \\
(3 \text { animal-derived })\end{array}$ \\
\hline & S. fusca (reference strain) & 2 \\
\hline & S. cinerea (reference strain) & 1 \\
\hline & S. asperula (reference strain) & 1 \\
\hline & Acremonium charticola & 1 \\
\hline & A. kiliense & 1 \\
\hline & Alternaria strictum & 1 \\
\hline & Alternaria alternata & 6 \\
\hline & A. brassicae & 3 \\
\hline & A. tenuissima & 1 \\
\hline & Alternaria sp. & 1 \\
\hline & Aspergillus flavus & 2 \\
\hline & A. fumigatus & 8 \\
\hline & A. clavatus & 3 \\
\hline & Cladosporium cladosporioides & 2 \\
\hline & C. macrocarpum & 1 \\
\hline & Fusarium solani & 1 \\
\hline & F. oxysporum & 1 \\
\hline & F. culmorum & 1 \\
\hline & Mucor racemosus & 2 \\
\hline & M. circinelloides & 1 \\
\hline & Ochrocladosporium elatum & 1 \\
\hline & Penicillium chrysogenum & 1 \\
\hline & P. commune & 2 \\
\hline & P. melinii & 1 \\
\hline & Penicillium sp. & 1 \\
\hline & P. digitatum & 1 \\
\hline & P. italicum & 1 \\
\hline & P. polonicum & 1 \\
\hline & P. crustosum & 1 \\
\hline & P. verrucosum & 1 \\
\hline & P. paneum & 1 \\
\hline & P. hirsutum & 1 \\
\hline & P. carneum & 1 \\
\hline
\end{tabular}

\begin{tabular}{|c|c|c|}
\hline \multicolumn{2}{|r|}{ Organism } & No of isolates \\
\hline \multirow[t]{6}{*}{ moulds } & Pleospora papaveracea & 1 \\
\hline & Rhizopus oryzae & 1 \\
\hline & R. oligosporus & 1 \\
\hline & Trichoderma viridae & 1 \\
\hline & Ulocladium tuberculatum & 1 \\
\hline & U. chartarum & 1 \\
\hline \multirow{17}{*}{$\begin{array}{l}\text { dermato- } \\
\text { phytes }\end{array}$} & Epidermophyton floccosum & 7 \\
\hline & Microsporum audouinii & 5 \\
\hline & M. canis & 3 \\
\hline & M. gypseum & 5 \\
\hline & M. nanum & 1 \\
\hline & M. persicolor & 3 \\
\hline & Trichophyton equinum & 1 \\
\hline & T. erinacei & 2 \\
\hline & T. interdigitale & 4 \\
\hline & T. mentagrophytes & 5 \\
\hline & T. rubrum & 4 \\
\hline & T. schoenleinii & 3 \\
\hline & T. soudanense & 2 \\
\hline & T. terrestrae & 6 \\
\hline & T. tonsurans & 6 \\
\hline & T. verrucosum & 5 \\
\hline & T. violaceum & 3 \\
\hline \multirow{13}{*}{$\begin{array}{l}\text { yeast-like } \\
\text { fungi }\end{array}$} & Candida albicans & 7 \\
\hline & C. catenulata & 1 \\
\hline & C. glabrata & 3 \\
\hline & C. guillermondii & 1 \\
\hline & C. kefyr & 2 \\
\hline & C. krusei & 1 \\
\hline & C. magnoliae & 1 \\
\hline & C. parapsilosis & 5 \\
\hline & C. tropicalis & 5 \\
\hline & C. utilis & 1 \\
\hline & Geotrichum sp. & 1 \\
\hline & Rhodotorula mucilaginosa & 1 \\
\hline & Saccharomyces cerevisiae & 1 \\
\hline \multicolumn{2}{|l|}{ Human } & 1 \\
\hline
\end{tabular}




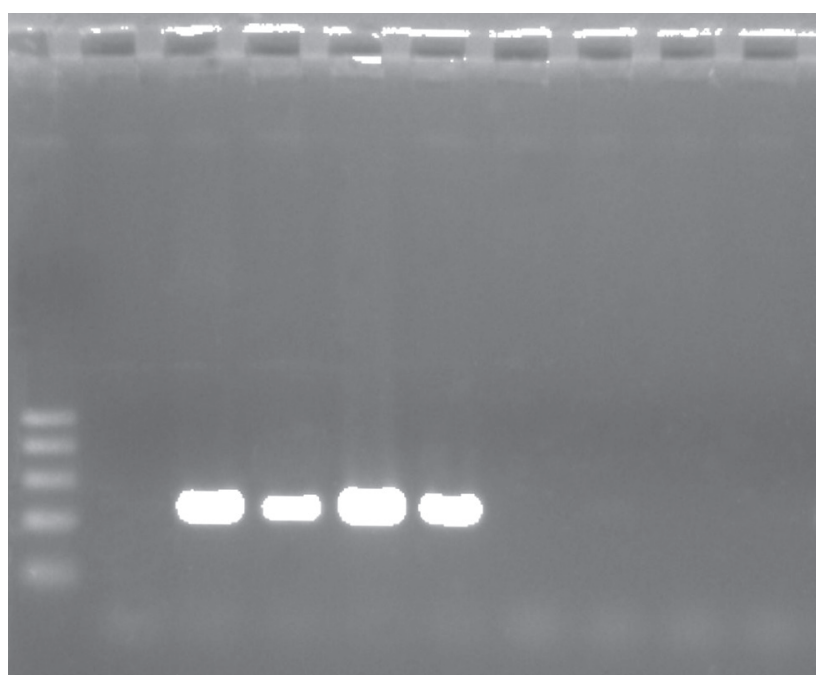

Fig. 1. Example of S. brevicaulis specific PCR product analysis. Lane 1 - molecular size marker (fragment sizes 500, 400, 300, 200 and $100 \mathrm{bp}$ ); results of S. brevicaulis-specific PCR performed for S. brevicaulis - reference strain (lane 3), human-derived isolate (lane 4), animal-derived isolates (lanes 5-6); S. fusca - reference strains (lanes 7-8); S. asperula (lane 9); S. cinerea (lane 10); negative control (lane 2).

lis reference strain, four clinical S. brevicaulis isolates, two $S$. fusca reference strains, one $S$. asperula reference strain, one S. cinerea reference strain and 56 other mould isolates, 65 dermatophyte isolates, 30 yeastlike isolates and one purified human DNA (Table I) were tested. $20 \mu \mathrm{l}$ PCR mixtures consisted of $10 \mu \mathrm{l}$ of $2 \times$ PCR Master Mix Plus High GC (A\&A Biotechnology, Poland), 0,1 $\mu$ l of each primer (Sbfor, Sbrev - Genomed, Poland) at $100 \mu \mathrm{M}$, and $2 \mu \mathrm{l}$ of DNA. PCR was performed in a Mastercycler ep gradient S-5345 (Eppendorf, Germany). The time-temperature profile for PCR started with initial denaturation for $3 \mathrm{~min} 94^{\circ} \mathrm{C}$ followed by 35 cycles of $30 \mathrm{~s}$ at $94^{\circ} \mathrm{C}, 30 \mathrm{~s}$ at $60^{\circ} \mathrm{C}$, and $30 \mathrm{~s}$ at $72^{\circ} \mathrm{C}$. The presence of specific PCR products of 223 bp was examined using electrophoresis on a $2 \%$ agarose gel and staining with ethidium bromide.

A 223-bp PCR product corresponding to S. brevicaulis was observed for 5/5 S. brevicaulis DNA samples. No PCR products were detected for S. asperula, S. cinerea, S. fusca reference strains, 56 other mould isolates, 65 dermatophyte isolates, 30 yeast-like isolates and one purified human DNA (100\% sensitivity and $100 \%$ specificity for PCR) (Fig. 1).

Nowadays, S. brevicaulis identification is based on macro- and microscopic observations. As these methods are laborious, time-consuming and requiring a pure culture for correct identification, they often produce misleading results (Jagielski et al., 2013). Especially diagnosis of disseminated S. brevicaulis infections is challenging for several reasons. First, disseminated S. brevicaulis infection is clinically difficult to distinguish from disseminated infection caused by
Aspergillus, Fusarium and zygomycosis. Second, in the immunocompromised organ transplant patient the sensitivity of confirmatory blood cultures is poor. There is no rapid blood test to confirm Scopulariopsis infection. Third, histopathologic evaluation of a cutaneous biopsy from a suspicious cutaneous lesion is not able to distinguish one disseminated mycelial infection from another. Aspergillus, Fusarium and other hyalohyphomycoses such as Scopulariopsis show identical morphology of biopsy specimens. To enable differentiation between the above listed mycelial fungi the tissue should be submitted for culture studies at the time of biopsy that delays the diagnosis for at least 1 week (Swick et al., 2010). So far, sequencing (Jagielski et al., 2013) and RFLP (Bontems et al., 2009) are the only molecular methods described for S. brevicaulis identification. However, these methods are still laborious and time-consuming. All of these factors indicate the need for development of methods that provide simple, rapid and highly specific identification of $S$. brevicaulis. In this study we present a PCR-based method that enables specific detection of S. brevicaulis within few hours. Application of primers Sbfor and Sbrev in PCR gives correct results among tested isolates. This potential of the described method as the diagnostic test should be evaluated further by testing patient specimens, because the applied procedure enables DNA extraction directly from specimens thus significantly reducing the time of diagnosis (Brillowska-Dąbrowska et al., 2010).

\section{Acknowledgements}

The authors wish to express their gratitude to A\&A Biotechnology (Gdynia, Poland) for the free provision of $2 \times$ PCR Master Mix Plus High GC. The authors wish to express their thanks to Prof. B. Dworecka-Kaszak, and I. Dąbrowska, MSc from the Department of Preclinical Sciences of Warsaw University of Life Sciences (Poland), Dr Med. A. Hryncewicz-Gwóźdź, and K. Kalinowska, MSc from the Department and Clinic of Dermatology, Venereology and Allergology of Wroclaw Medical University for the identification and delivery of $S$. brevicaulis isolates.

\section{Literature}

Anandan V., V. Nayak, S. Sundaram and P. Srikanth. 2008. An association of Alternaria alternata and Scopulariopsis brevicaulis in cutaneous phaeohyphomycosis. Indian J. Dermatol. Venereol. Leprol. 74(3): 244-247.

Besbes M., F. Makni, F. Cheikh-Rouhou, H. Sellami, K. Kharrat and A. Ayadi. 2002. Otomycosis due to Scopulariopsis brevicaulis. Rev. Laryngol. Otol. Rhinol. (Bord) 123(2): 77-78.

Brillowska-Dąbrowska A., S.S. Nielsen, H.V. Nielsen and M.C. Arendrup. 2010. Optimized 5-h multiplex PCR test for the detection of tinea unguium: performance in a routine PCR laboratory. Med. Mycol. 48(6): 828-831.

Bontems O., P.M. Hauser and M. Monod. 2009. Evaluation of a polymerase chain reaction-restriction fragment length polymorphism 
assay for dermatophyte and nondermatophyte identification in onychomycosis Brit. J. Dermatol. 161(4): 791-796.

Bryuynzel I. and T.M. Starink. 1998. Granulomatous skin infection caused by Scopulariopsis brevicaulis. Acta Derm. Venereol. 39: 365-367.

Cuenca-Estrella M., A. Gomez-Lopez, E. Mellado, M.J. Buitrago, A. Monzon and J.L. Rodriguez-Tudela. 2003. Scopulariopsis brevicaulis, a fungal pathogen resistant to broad-spectrum antifungal agents. Antimicrob. Agents Chemother. 47(7): 2339-2341.

Del Prete A., G. Sepe, M. Ferrante, C. Loffredo, M. Masciello and A. Sebastiani. 1994. Fungal keratitis due to Scopulariopsis brevicaulis in an eye previously suffering from herpetic keratitis. Ophthalmologica. 208(6): 333-335.

Dhar J. and P.B. Carey. 1993. Scopulariopsis brevicaulis skin lesions in an AIDS patient. AIDS. 7(9): 1283-1284.

Endo S., M. Hironaka, F. Murayama, T. Yamaguchi, Y. Sohara and K. Saito. 2002. Scopulariopsis fungus ball. Ann. Thorac. Surg. 74(3): 926-927.

Filipello Marchisio V., A. Fusconi and F.L. Querio. 2000. Scopulariopsis brevicaulis: a keratinophilic or keratinolytic fungus? Mycoses. 43: 281-292.

Gariano R.F. and R.E. Kalina. 1997. Posttraumatic fungal endophthalmitis resulting from Scopulariopsis brevicaulis. Retina. 17(3): 256-258.

Gentry L.O., N.M. Nasser and M. Kielhofner. 1995. Scopulariopsis endocarditis associated with Duran ring valvuloplasty. Tex. Heart Inst. J. 22(1): 81-85.

Gluck O., N. Segal, F. Yariv, I. Polacheck, M. Puterman, D. Greenberg and B. Daniel. 2011. Pediatric invasive sinonasal Scopulariopsis brevicaulis- a case report and literature review. Int. J. Pediatr. Otorhinolaryngol. 75(7): 891-893.

Gupta A.K., C. Drummond-Main, E.A. Cooper, W. Brintnell, B.M. Piraccini and A. Tosti. 2012. Systematic review of nondermatophyte mold onychomycosis: Diagnosis, clinical types, epidemiology, and treatment. J. Am. Dermatol. 66(3): 494-502.

Hart A.P., D.A. Sutton, P.J. McFeeley and M. Kornfeld. 2001. Cerebral phaeohyphomycosis caused by a dematiaceous Scopulariopsis species. Clin. Neuropathol. 20(5): 224-228.

Hennequin C., M. el-Bez, J. Trotoux and M. Simonet. 1994. Scopulariopsis brevicaulis otomycosis after tympanoplasty. Ann. Otolaryngol. Chir. Cervicofac. 111(6): 353-354.

Issakainen J., J.H. Salonen, V.J. Anttila, P. Koukila-Kähkölä, M. Castrén, O. Liimatainen, R. Vuento, T. Ojanen, I. Koivula, M. Koskela and others. 2010. Deep, respiratory tract and ear infections caused by Pseudallescheria (Scedosporium) and Microascus (Scopulariopsis) in Finland. A 10-year retrospective multi-center study. Med. Mycol. 48(3): 458-465.
Jagielski T., K. Kosim, M. Skóra, A.B. Macura and J. Bielecki. 2013. Identification of Scopulariopsis species by partial $28 \mathrm{~S}$ rRNA gene sequence analysis. Pol. J. Microbiol. 62(3): 303-306.

Jain D., J.K. Oberoi, S.K. Shahi, G. Shivnani and C. Wattal. 2011. Scopulariopsis brevicaulis infection of prosthetic valve resembling aspergilloma on histopathology. Cardiovasc. Pathol. 20(6): 381-383. Krisher K.K., N.B. Holdridge, M.M. Mustafa, M.G. Rinaldi and D.A. McGough. 1995. Disseminated Microascus cirrosus infection in pediatric bone marrow transplant recipient. J. Clin. Microbiol. 33(3): 735-737.

Lotery A.J., J.R. Kerr and B.A. Page. 1994. Fungal keratitis caused by Scopulariopsis brevicaulis: successful treatment with topical amphotericin B and chloramphenicol without the need for surgical debridement. Br. J. Ophthalmol. 78(9): 730.

Migriono R.Q., G.S. Hall and D.L. Longworth. 1995. Deep tissue infections caused by Scopulariopsis brevicaulis: report of a case of prosthetic valve endocarditis and review. Clin. Infect. Dis. 21(3): 672-674. Neglia J.P., D.D. Hurd, P. Ferrieri and D. C. Snover. 1987. Invasive Scopulariopsis in the immunocompromised host. Am. J. Med. 83(6): 1163-1166.

Phillips P., W.S. Wood, G. Phillips and M.G. Rinaldi. 1989. Invasive hyalohyphomycosis caused by Scopulariopsis brevicaulis in a patient undergoing allogeneic bone marrow transplant. Diagn. Microbiol. Infect. Dis. 12(5): 429-342.

Salmon A., A. Debourgogne, M. Vasbien, L. Clément, J. Collomb, F. Plénat, P. Bordigoni and M. Machouart. 2010. Disseminated Scopulariopsis brevicaulis infection in an allogeneic stem cell recipient: case report and review of the literature. Clin. Microbiol. Infect. 16(5): 508-512.

Satyavani M., R. Viswanathan, N.S. Harun and L. Mathew. 2010. Pulmonary Scopulariopsis in a chronic tobacco smoker. Singapore Med. J. 51(8): 137-139.

Stefanato C.M. and R. Verdolini. 2009. Histopathologic evidence of the nondermatophytic mould Scopulariopsis brevicaulis masking the presence of dermatophytes in a toenail infection. J. Cutan. Pathol. 36(Suppl. 1): 8-12.

Swick B.L., S.C. Reddy, A. Friedrichs and M.S. Stone. 2010. Disseminated Scopulariopsis- culture is required to distinguish from other disseminated mould infections. J. Cutan. Pathol. 37: 687-691. Vignon M., D. Michonneau, M.T. Baixench, C. Al-Nawakil, D. Bouscary, A. Buzyn, D. Salmon and A. Paugam. 2011. Disseminated Scopulariopsis brevicaulis infection in an allogeneic stem cell recipient. Bone Marrow Transplant. 46(9): 1276-1277.

Wuyts W.A., H. Molzahn, J. Maertens, E.K. Verbeken, K. Lagrou, L.J. Dupont and G.M. Verleden. 2005. Fatal Scopulariopsis infection in a lung transplant recipient: a case report. J. Heart Lung Transplant. 24(12): 2301-2304. 